\title{
Ectopic lingual thyroid with vascular anomalies
}

\author{
This article was published in the following Dove Press journal: \\ International Medical Case Reports Journal \\ 3 September 2013 \\ Number of times this article has been viewed
}

\section{Maria Rita Bianco \\ Alessandro La Boria \\ Teresa Franco \\ Pierpaolo Ferrise \\ Eugenia Allegra}

Department of OtolaryngologyHead and Neck Surgery, University of Catanzaro, Catanzaro, Italy
Correspondence: Eugenia Allegra Unità Operativa di Otorinolaringoiatria, Università "Magna Graecia” di Catanzaro, Viale Europa, Località Germaneto, 88100 Catanzaro, Italy Tel +39096I 3647130 Fax+390961364 7131

Email eualle@unicz.it
Background: Lingual thyroid represents $90 \%$ of ectopic thyroid tissue localizations. The first case was described by Hickman in 1869. An ectopic thyroid is often asymptomatic, but pathological or physiological conditions inducing hyperproduction of thyroid-stimulating hormone can lead an ectopic thyroid to become symptomatic. Treatment of the symptomatic ectopic thyroid can be medical, with hormone-suppressing therapy, or surgical.

Case presentation: A 17-year-old female presented to our outpatient clinic complaining of a sensation of a lump in her throat. Ear, nose, and throat (ENT) examination identified a swelling of the base of the tongue in the glossoepiglottic area. Thyroid scintigraphy showed a single contrast enhancement in the sublingual region, instead of in the normal anatomical position of the thyroid. She was treated surgically after failed hormone-suppressing therapy. An arteriography performed before the surgery showed vascular anomalies and was useful in surgical planning.

Conclusion: Recognition of vascular anomalies in an ectopic thyroid is fundamental before surgical planning, therefore, accurate radiological study of the vasculature should always be planned before surgical treatment of this disease.

Keywords: ectopic thyroid, arteriography, transoral approach, tongue

\section{Background}

The thyroid gland derives from the endodermic tissue of the primitive pharynx and arises between the first and second brachial arches. The thickening of the primitive pharyngeal floor expands downwards in a diverticulum and maintains contact with the pharyngeal floor through the thyroglossal duct.

The thyroid precursor follows the descent of the heart and major vessels and develops downwards and in front of the growing hyoid bone. When thyroid development is complete, the thyroglossal duct atrophies, and only a small remnant persists at the end of third posterior segment of the tongue (foramen cecum). ${ }^{1}$

The most common site of an ectopic thyroid is in the downward path of the precursor, between the foramen cecum and the hyoid bone. Ninety per cent of ectopic thyroids have a lingual localization. ${ }^{1}$ The definition of lingual thyroid can be used only if thyroid tissue is present on the base of the tongue between the epiglottis and circumvallate papillae, and if it picks up ${ }^{131} \mathrm{I}$ at thyroid scintigraphy. ${ }^{2,3}$ The first case of ectopic lingual thyroid was described by Hickman in $1869 .{ }^{4}$

Lingual thyroid is often asymptomatic, but increased levels of thyroid stimulating hormone (TSH) caused by puberty, pregnancy, or stress can lead an ectopic thyroid 
to become symptomatic. Symptom severity depends on the size of the ectopic lingual tissue. In pediatric patients, it can cause sleep apnea and laryngeal stridor. ${ }^{5}$ We describe a case of lingual thyroid with a rare vascular anomaly in a 17-year-old female.

\section{Case presentation}

A 17-year-old female presented to our outpatient clinic complaining of a sensation of a lump in her throat and moderate dysphagia following an episode of acute rhinopharyngitis. Her height was $158 \mathrm{~cm}$ and weight was $63 \mathrm{~kg}$. The patient had no family history of metabolic abnormalities. The ear, nose and throat examination identified a swelling of the base of the tongue. The swelling appeared round with an approximate diameter of $3 \mathrm{~cm}$; it was near the foramen cecum; it had a reddish color; and it had an irregular nonulcerated surface. Fiberoptic endoscopy identified the swelling in the glossoepiglottic area (Figure 1). It was mobile during deglutition. A thyroid scintigraphy, with technetium-99 pertechnetate, showed a single contrast enhancement in the sublingual region, instead of in the normal anatomical position of the thyroid (Figure 2). Determination of blood levels of the thyroid hormones showed a free triiodothyronine (FT3) of $3.0 \mathrm{pg} / \mathrm{mL}$ (normal range: $2.4-4.2 \mathrm{pg} / \mathrm{mL}$ ), a free tetraiodothyronine (FT4) of $1.0 \mathrm{ng} / \mathrm{dL}$ (normal range: $0.8-1.7 \mathrm{ng} / \mathrm{dL}$ ), and $\mathrm{TSH}$ of $5 \mathrm{IU} / \mathrm{mL}$ (normal range $0.3-5.0 \mathrm{IU} / \mathrm{mL}$ ).

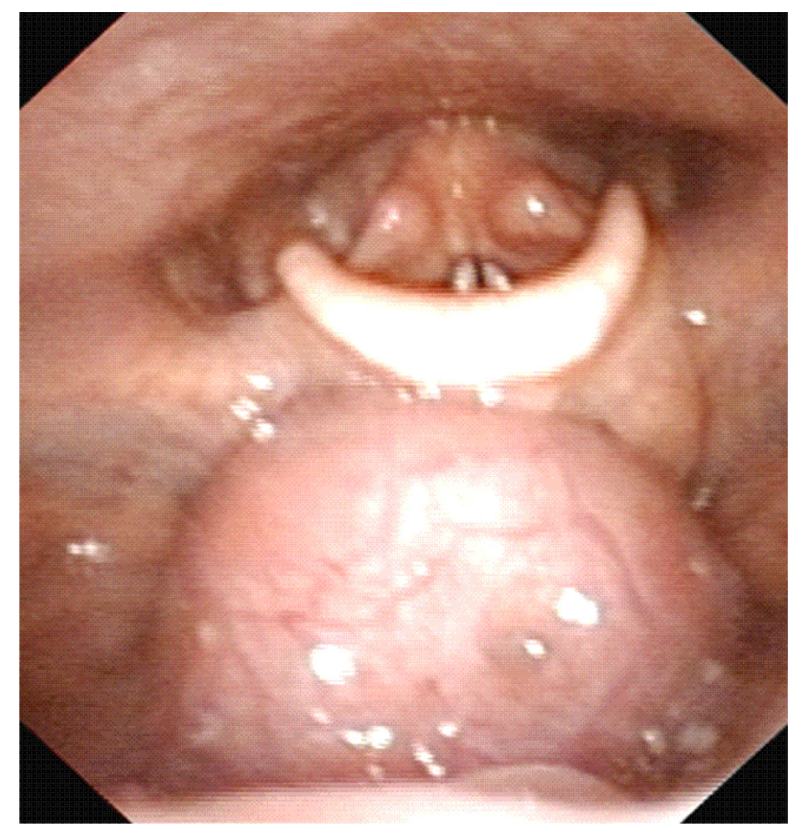

Figure I Endoscopic examination revealing a swelling in the glossoepiglottic space close to the foramen cecum, with an approximate diameter of $3 \mathrm{~cm}$, reddish color and with an irregular nonulcerated surface.

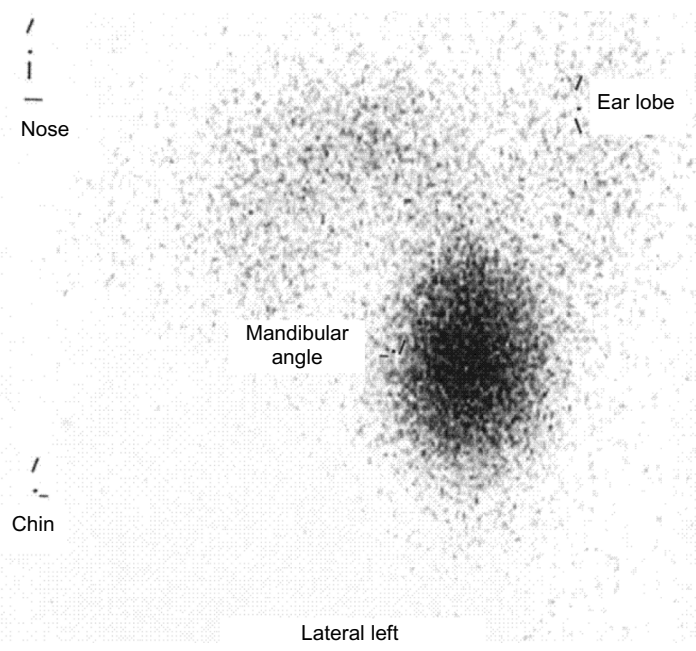

Figure 2 Thyroid scintigraphy showing a single contrast enhancement at the back of the lingual region, instead of in the normal anatomic position.

The patient started medical suppressive therapy with levothyroxine $25 \mathrm{mcg} /$ day for the first 2 weeks and $50 \mathrm{mcg} /$ day for the next 9 months, but no reduction in either swelling or symptoms was observed, so she was scheduled for surgical treatment.

A preoperative neck computed tomography (CT) identified an nonhomogeneous, hyperdense soft tissue with distinct margins and round shape at the base of the tongue, with a maximum diameter of $3 \mathrm{~cm}$, and absence of the thyroid gland.

The vascularization of the mass was evaluated through carotid arteriography. The mass was vascularized by collateral branches of the lingual arteries in its anterior and posterior regions. The superior and inferior thyroid arteries were bilaterally absent (Figure 3 ).

Surgery was then performed using a transoral approach, under general anesthesia. The mass was removed, with an electrosurgical needle, along a cleavage plane from the foramen cecum backwards to the glossoepiglottic vallecula;
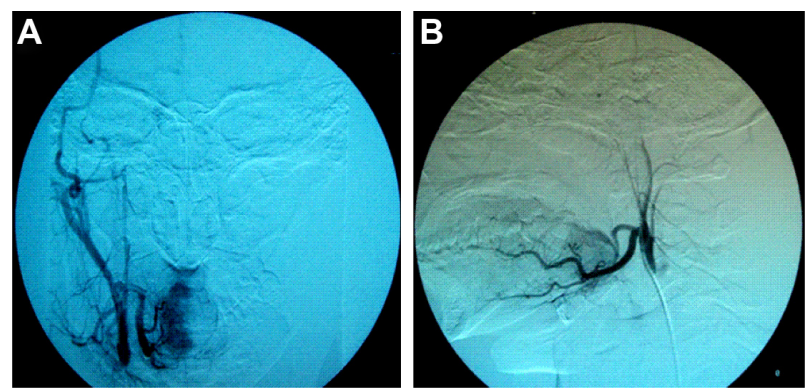

Figure 3 Carotid arteriography showing that superior and inferior thyroid arteries were bilaterally absent and that the mass was supplied by small collateral branches of the lingual arteries: (A) anterior view and (B) lateral view. 
hemostasis was adequate. A surgical reconstruction of the base of the tongue was performed by suturing the remaining area of the tongue, and a nasogastric tube was inserted. The nasogastric tube was removed 6 days after surgery, and the patient was discharged a day later with hormone replacement therapy, without deficiency in swallowing or speaking.

The hormone replacement therapy was based on thyroxine tablets $50 \mu \mathrm{g} /$ day.

Histologically, the mass was found to be "thyroid tissue with alternation of hyperplastic and colloid cystic areas, coated with a layer of squamous epithelium." The surgical specimen measured $3 \times 3 \mathrm{~cm}$ (Figure 4 ).

\section{Discussion}

The aim of surgical treatment of lingual thyroid should be to eliminate obstructive symptoms and to prevent hemorrhagic complications and deforming or incapacitating surgical scars. This concept is even more important when considering that the majority of diagnoses are performed in young subjects, often female, with few or no symptoms. Hormone-suppressive treatment must be the initial therapeutic strategy, although a significant reduction is rarely achieved. Thus, in most cases surgery becomes unavoidable.

The surgery can be performed using a transoral approach, a transhyoid approach, a lateral pharyngotomy approach, or a combination of these methods. The technique choice is influenced by patient age and sex, symptoms, dimensions, the localization of the mass, and above all, by the ability to control bleeding. ${ }^{6}$

The transoral approach provides good exposure and is less traumatic for the patient, with better postoperative

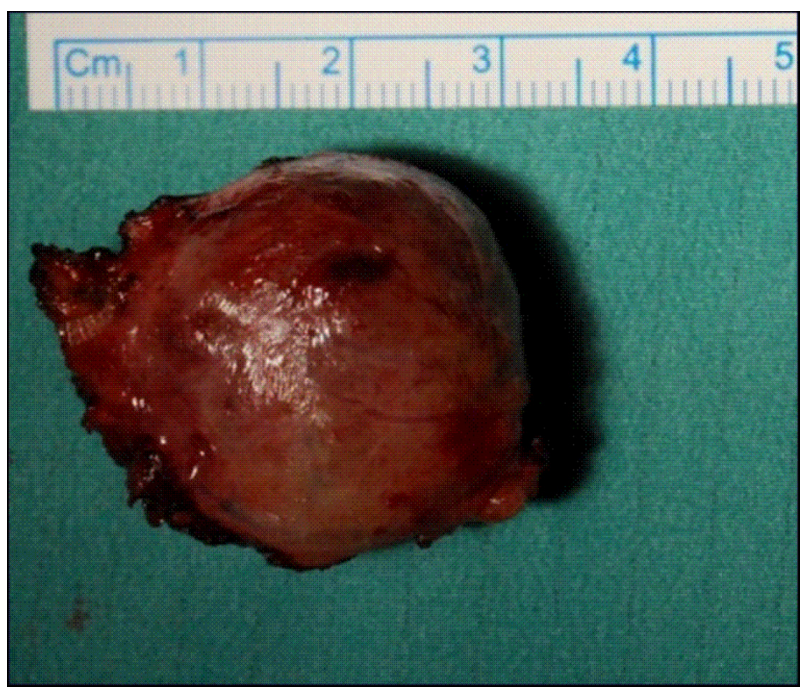

Figure 4 Surgical specimen. recovery and unsightly scars. ${ }^{7}$ However, this approach can be feasible only for small masses, and it is necessary to identify the vascular supply of the ectopic thyroid because transoral surgery has a lesser possibility of bleeding control due to the narrowness of the operative field.

Our patient was a young female with a retrolingual mass already visible with oroscopy, therefore a transoral approach was planned.

The preoperative arteriography showed the mass was vascularized by small branches of the lingual arteries and the absence of thyroid arteries. This peculiar vascularization put the transoral approach at lesser risk of bleeding.

Studies on cadavers have identified anomalies of the thyroid arteries: the superior is often absent, while the inferior, if present, appears hypoplastic, and the lingual thyroid is vascularized by lingual or facial arteries. ${ }^{8,9}$ Thus, our case represents the second report in which a preoperative arteriography identified small collateral branches of the lingual arteries supplying a lingual thyroid. ${ }^{10}$

A recent study demonstrated that in the embryogenesis and migration of the thyroid gland, two phases can be distinguished. In the first phase, the thyroid precursor has a direct relationship with the cardiac flow. In a second phase, thyroid migration follows the development of the ventral aorta and the carotid arteries. Abnormal vascular development at this phase can cause a total halt of thyroid migration. ${ }^{11}$

Angiography should be performed in all of the cases of lingual thyroid, especially when a transoral approach is planned. This improves the possibility of bleeding control and influences the decision regarding surgical approach.

Once the vascularization is known, intraoperative bleeding can be prevented through embolization of the lingual artery branches as described in literature. ${ }^{12,13}$

Radioiodine therapy can reduce the lingual thyroid dimensions and can be an alternative to surgery in mildly or asymptomatic patients without complaints of obstruction. ${ }^{14,15}$

\section{Conclusion}

An accurate radiological study of the vasculature should always be planned before surgical treatment of an ectopic thyroid. The recognition of vascular anomalies in an ectopic lingual thyroid is fundamental and influences surgical planning.

\section{Disclosure}

The authors report no conflicts of interest in this work.

\section{References}

1. Rahbar R, Yoon MJ, Connolly LP, et al. Lingual thyroid in children: a rare clinical entity. Laryngoscope. 2008;118(7):1174-1179. 
2. Montgomery ML. The lingual thyroid: a comprehensive review. West $J$ Surg Obstet Gynecol. 1936;44:442-446.

3. Ward GE, Cantrell JR, Allan WB. The surgical treatment of lingual thyroid. Ann Surg. 1954;139(5):536-543.

4. Hickman W. Congenital tumour of the base of the tongue, pressing down on the epiglottis and causing death by suffocation sixteen hours after birth. Trans Pathol Soc Lond. 1869;20:160-161.

5. Maddern BR, Werkhaven J, McBride T. Lingual thyroid in a young infant presenting as airway obstruction: report of a case. Int $J$ Pediatr Otorhinolaryngol. 1988;16(1):77-82.

6. Mussak EN, Kacker A. Surgical and medical management of midline ectopic thyroid. Otolaryngol Head Neck Surg. 2007;136(6):870-872.

7. Amr B, Monib S. Lingual thyroid: A case report. Int J Surg Case Rep. 2011;2(8):313-315.

8. Bergman RA, Thomson SA, Afifi AK, Saadeh FA. Compendium of human anatomic variation. In: Endocrine System. Baltimore, MD: Urban and Schwarzenber. 1988;175.

9. Banna M, Lasjaunias P. The arteries of the lingual thyroid: angiographic findings and anatomic variations. AJNR Am J Neuroradiol. 1990;11(4): 730-732.
10. Ramesh RT, Balakrishnan R, Prakashchandra S, Suresh R. Ectopic thyroid tissue with a rare vascular variation. Int J Morphol. 2007; 25(1):121-124.

11. Alt B, Elsalini OA, Schrumpf P, et al. Arteries define the position of the thyroid gland during its developmental relocalisation. Development. 2006;133(19):3797-3804.

12. Chiu TT, Su CY, Hwang CF, Chien CY, Eng HL. Massive bleeding from an ectopic lingual thyroid follicular adenoma during pregnancy. Am J Otolaryngol. 2002;23(3):185-188.

13. Scherer K, Kramann B, Herwig U. Embolization of a bleeding lingual thyroid. Rofo. 1988;149(6):671-672. German.

14. Park HM, Gupta S, Skierczynski P. Radioiodine-131 therapy for lingual thyroid. Thyroid. 2003;13(6):607.

15. Jacob MJ, Ravina M. A rare case of lingual thyroid with hyperthyroidism: A case report and review of the literature. Indian $J$ Endocrinol Metab. 2012;16(3):441-443.
International Medical Case Reports Journal

\section{Publish your work in this journal}

The International Medical Case Reports Journal is an international, peer-reviewed open-access journal publishing original case reports from all medical specialties. Previously unpublished medical posters are also accepted relating to any area of clinical or preclinical science. Submissions should not normally exceed 2,000 words or

\section{Dovepress}

4 published pages including figures, diagrams and references. The manuscript management system is completely online and includes a very quick and fair peer-review system, which is all easy to use. Visit http://www.dovepress.com/testimonials.php to read real quotes from published authors.

Submit your manuscript here: http://www.dovepress.com/international-medical-case-reports-journal-journal 